\title{
Chronic Postoperative Pain: Comprehending It to Intervene
}

\section{Dor crônica pós-operatória: Compreender para intervir}

\author{
Lorraine Ariel Duarte Oliveira ${ }^{1}$ Carolina Alves Araújo Rocha ${ }^{1}$ Ledismar José Silva ${ }^{1}$ \\ ${ }^{1}$ School of Medicine, Pontifícia Universidade Católica de Goiás (PUC- \\ Goiás), Goiânia, GO, Brazil \\ Address for correspondence Ledismar José da Silva, MSc, School of \\ Medicine, Pontifícia Universidade Católica de Goiás (PUC-Goiás), \\ Avenida Universitária, 1440, Setor Universitário, Goiânia, GO, 74605- \\ Arq Bras Neurocir 2020;39(3):170-180. \\ 010, Brazil (e-mail: ledismarsilva@gmail.com).
}

\begin{abstract}
Keywords

- postoperative pain

- chronic pain

- pain management
\end{abstract}

\section{Resumo}

It is estimated that between 266.2 and 359.5 million operations were performed in 2012 worldwide, and this number is on the rise. Chronic postoperative pain (CPOP) is the most important and still neglected postoperative complication, with a multifactorial causality, leading to a major impact on morbidity rates, high costs for the public health system, and direct and negative effects on the quality of life of the patients. The present systematic literature review aimed to elucidate the processes of postoperative pain chronification, biopsychosocial factors, risk factors, management of pain, and types of surgical procedures mainly associated with it. The review was based on the methodological recommendations of Preferred Reporting Items for Systematic Reviews and Meta-Analyses (PRISMA). The following databases were consulted: the Medical Literature, Analysis, and Retrieval System Online (MEDLINE), the Latin American and Caribbean Health Sciences Literature (LILACS), the Scientific Electronic Library Online (SCiELO), and the Cochrane Central Register of Controlled Trials (CENTRAL). After reading the selected articles, the following surgical specialties were chosen to be addressed: general, orthopedics, breast cancer, gynecology, obstetrics, and thoracic. In conclusion, a deficient management of acute postoperative pain is the main risk factor for the development of CPOP. To prevent CPOP, training programs for healthcare professionals should be implemented to improve their skills and knowledge of the management of pain before, during, and after surgeries. It is also necessary to conduct more in-depth studies on the evaluation and management of this condition.

Estima-se que entre 266,2 e 359,5 milhões de cirurgias tenham sido realizadas em 2012 no mundo todo, e este número tende a crescer. A dor crônica pós-operatória (DCPO) é a complicação pós-cirúrgica mais importante e ainda negligenciada, com causalidade multifatorial, resultando em grande impacto nas taxas de morbidade, altos custos para o sistema de saúde, e efeitos diretos e negativos na qualidade de vida dos pacientes. Esta revisão sistemática da literatura teve por objetivo elucidar os processos de cronificação da dor pós-operatória, os fatores biopsicossociais, os fatores de risco, o manejo da dor, e os principais tipos de intervenção cirúrgica associados a ela. A revisão foi realizada com base nas recomendações de "Preferred Reporting Items for

received

June 7, 2019

accepted

October 22, 2019
DOI https://doi.org/

$10.1055 / \mathrm{s}-0039-3402489$. ISSN $0103-5355$
Copyright $\odot 2020$ by Thieme Revinter

Publicações Ltda, Rio de Janeiro, Brazil
License terms

()ㅇㅇ $\Theta \circledast$ 
Palavras-chave

- dor pós-operatória

- dor crônica

- manejo da dor
Systematic Reviews and Meta-Analyses (PRISMA)". As bases de dados consultadas foram: Medical Literature, Analysis, and Retrieval System Online (MEDLINE), Literatura Latino-Americana e do Caribe em Ciências da Saúde (LILACS), Scientific Electronic Library Online (SciELO) e Cochrane Central Register of Controlled Trials (CENTRAL). Após a leitura dos artigos selecionados, as seguintes especialidades cirúrgicas foram escolhidas para abordagem: geral, ortopédica, mastológica, ginecológica, obstétrica e torácica. Em conclusão, o manejo deficiente da dor aguda pós-operatória é o principal fator de risco para o desenvolvimento da DCPO. Para prevenir a DCPO, é aconselhável implementar programas de treinamento para os profissionais da saúde de modo a melhorar suas habilidades e conhecimentos no que concerne o manejo da dor antes, durante e após procedimentos cirúrgicos. Também é necessário desenvolver estudos mais aprofundados acerca da avaliação e do manejo da DCPO.

\section{Introduction}

It is estimated that between 266.2 and 359.5 million operations were performed in 2012 worldwide, and this number is on the rise. ${ }^{1}$ Surgical procedures, like any type of aggression to the body, trigger immunological and metabolic responses to trauma as part of the adaptive response to the survival of the organism. The patient then reacts with anxiety and fear, feelings that may be present before, during, and after surgeries.

Pain persistence after surgical procedures is an important patient complaint. The International Association for the Study of Pain (IASP) defines pain as any unpleasant sensory and emotional experience associated with a present or potential tissue injury or described as this by the patient. ${ }^{2}$ Therefore, pain is evidenced as a complex phenomenon that encompasses sensorial-discriminative and affective-motivational components. ${ }^{3}$

Despite the advances in the medical field, postoperative pain is still neglected and not properly treated. The consequences include decreased quality of life and increased morbidity and mortality rates. The acceptance of pain as a natural and predictable phenomenon after surgery corroborates healthcare professional negligence in spite of the patients' complaints. As a result, the patient sometimes stops complaining. Adequate management of acute postoperative pain (APOP) relieves suffering and favors early mobilization, thus shortening the average length of hospital stay and reducing costs. However, chronic postoperative pain (CPOP) is likely to occur after an episode of APOP that was not adequately treated. ${ }^{4}$ The consequences of CPOP are of great importance, because in addition to causing suffering for patients and reducing their quality of life, it is also a burden on the health care and social support systems worldwide.

In summary, CPOP is a syndrome with its own characteristics, which may result from an isolated inflammatory process, neural damage, or a combination of these factors. ${ }^{5}$ An up-todate definition of CPOP includes the following criteria: pain developed after a surgical procedure or increased in intensity after it; pain should last at least 3 to 6 months and significantly affect the patient's quality of life; pain is a continuation of APOP or has developed after an asymptomatic period; pain is located in the surgical field, projected to the innervation territory of a nerve located at the site of the incision, or referred to a dermatome; other causes of pain should be excluded. ${ }^{6}$

Nevertheless, these criteria are usually not followed by healthcare professionals, since they have not been prepared to observe them. This deficiency in training makes recording the real incidence of CPOP almost impossible. In spite of this, it is well accepted that CPOP is the main surgical complication of APOP. ${ }^{4,5}$

Therefore, the present systematic literature review aimed to elucidate the processes of postoperative pain chronification, as well as the biopsychosocial factors, risk factors, management of pain, and types of surgical procedures mainly associated with it.

\section{Materials and Methods}

A systematic literature review was conducted based on the recommendations of the Preferred Reporting Items for Systematic Reviews and Meta-Analyses (PRISMA). The following databases were consulted: the Medical Literature, Analysis, and Retrieval System Online (MEDLINE), the Latin American and Caribbean Health Sciences Literature (LILACS), the Scientific Electronic Library Online (SciELO), and the Cochrane Central Register of Controlled Trials (CENTRAL). The search descriptors employed, associated with Boolean operators, were as follows: postoperative chronic pain, postsurgical pain, and chronic pain.

During article selection, the following inclusion criteria were adopted: 1) full-length original articles; 2) articles published within the past five years; 3 ) observational studies, randomized studies, or guidelines; and 4) articles written in Portuguese, English, or Spanish.

The exclusion criteria elected for the current review were: 1) studies involving animals; 2) studies involving children (under 18 years of age); 3) publications such as letters, comments, unpublished manuscripts, dissertations, government reports, and classes; 4) definition of chronic pain not meeting that of the IASP; 5) comparisons of medications, anesthetics, and/or surgical techniques; 6) studies with a 
restricted focus on specific populations and/or regions; 7) prior use of opioids; and 8) previous chronic pain.

\section{Results}

During the literature review, a total of 25 papers were selected (-Fig. 1, - Table 1). After reading the selected articles, the following surgical specialties were chosen to be addressed: orthopedic, gynecologic, obstetric, breast cancer, general, and thoracic.

\section{Physiopathology of CPOP}

The patients submitted to surgery present with tissue injury, which in turn locally releases chemical mediators that modify the environment where the nociceptors are located. This changes the depolarization threshold and causes a hyperalgesic response after the procedure. The $C$ and $A \delta$ fibers are sensitized, leading to non-evoked pain. Several factors contribute to the sensitization of nociceptors after surgery, such as $\mathrm{pH}$ reduction, lactate elevation, reduction of local oxygen tension, and activation of acid-sensitive ion channels. ${ }^{4}$

Sensitization is an increase in the effectiveness of synaptic driving. It manifests locally-peripherally with the release of chemical mediators of injured tissue and immune system cells that activate receptors of the neural membrane of the primary afferent of the $\mathrm{C}$ and AS fibers. Thus, chemical, mechanical, or thermal stimuli are transformed into electrical stimuli. Synapses are formed between these fibers and neurons from the posterior horn of the spinal cord, and they conduct the painful stimulus through the lateral spinothalamic tract to the nuclei responsible for the cognitive evaluation of cerebral cortex pain. The nociceptive impulse leads to an increase in the neuronal excitability of the central nervous system (CNS), generating central sensitization. Thus, the persistence and intensity of the painful stimulus lead to a decrease in the excitatory threshold of the nociceptor, which may cause allodynia or hyperalgesia. Subsequently, a repetitive activation of $C$ fibers and a feedback of this process, added to sensory information processed in an atypical way, causes an alteration in peripheral and central neuroplasticity. This can last a long time after the initial lesion has healed, resulting in years of pain, characterizing the process of pain chronification. $^{5}$

\section{Risk Factors for CPOP}

Chronic postoperative pain is associated with several preoperative, intraoperative, and postoperative risk factors, which

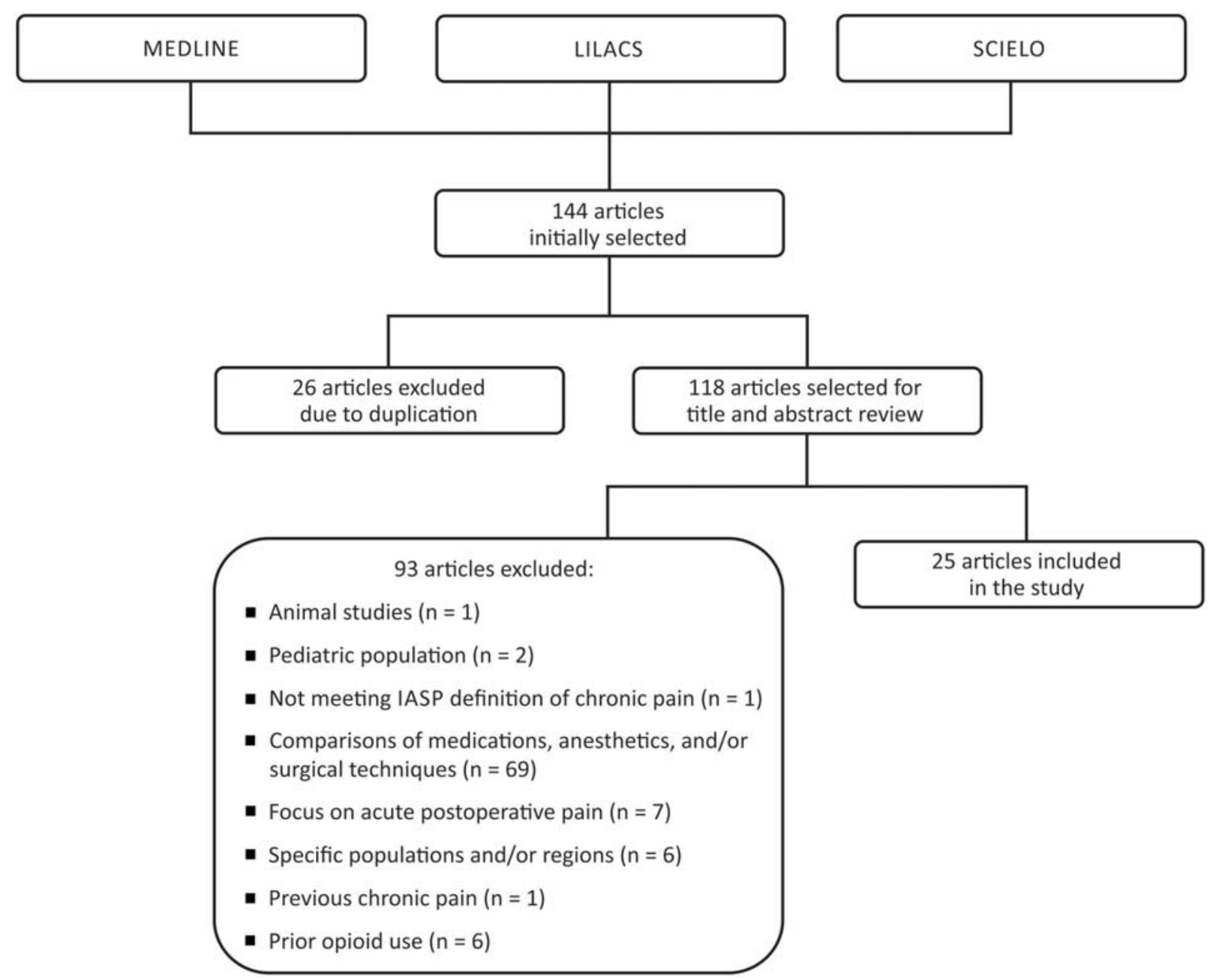

Fig. 1 Data collection during this systematic literature review. 
Table 1 Articles selected in this systematic literature review

\begin{tabular}{|c|c|c|c|c|c|}
\hline Design & Procedure & Sample & Follow-up & Conclusion & Reference \\
\hline $\begin{array}{l}\text { Retrospective } \\
\text { study }\end{array}$ & $\begin{array}{l}\text { Laparoscopic/open } \\
\text { nephrectomy, } \\
\text { laparoscopic/open } \\
\text { prostatectomy, } \\
\text { adenomectomy, } \\
\text { cystectomy, } \\
\text { prostatic cystectomy, } \\
\text { laparoscopic hernia, } \\
\text { open surrenalectomy, } \\
\text { orchidectomy, renal } \\
\text { transplant, pelvectomy, } \\
\text { laparoscopic } \\
\text { promontofixation }\end{array}$ & 523 patients & $\begin{array}{l}3 \text { months after } \\
\text { surgery }\end{array}$ & $\begin{array}{l}\text { Preoperative pain reported by } \\
8 \% \text { of the patients; chronic } \\
\text { postoperative pain (CPOP) } \\
\text { reported by } 24 \% \text { ( } 6 \text { months } \\
\text { after surgery); neuropathic } \\
\text { pain reported by } 36 \% \text {. Patients } \\
\text { with CPOP had significantly } \\
\text { more preoperative pain and } \\
\text { increased morphine use in the } \\
\text { postoperative period. Postop- } \\
\text { erative administration of non- } \\
\text { steroidal anti-inflammatory } \\
\text { drugs (NSAIDs) led to lower } \\
\text { levels of persistent pain. }\end{array}$ & Artus et $\mathrm{al}^{7}$ \\
\hline $\begin{array}{l}\text { Prospective } \\
\text { cohort }\end{array}$ & $\begin{array}{l}\text { Surgical excision of tumor } \\
\text { with or without removal of } \\
\text { axillary lymph nodes }\end{array}$ & $\begin{array}{l}406 \text { women recruited: } 338 \\
\text { with full preoperative data; } \\
308 \text { eligible for analysis at } \\
4 \text { months; } 293 \text { eligible for } \\
\text { analysis at } 9 \text { months }\end{array}$ & $\begin{array}{l}\text { Preoperative, } \\
1 \text { week, } 4 \text { months, } \\
\text { and } 9 \text { months } \\
\text { after surgery }\end{array}$ & $\begin{array}{l}210 \text { out of } 308 \text { (68\%) women } \\
\text { reported chronic pain at } \\
4 \text { months, and } 184 \text { out of } 293 \\
\text { ( } 63 \%) \text {, at } 9 \text { months. Nine } \\
\text { variables were included in the } \\
\text { multiple logistic regression } \\
\text { models, predicting chronic } \\
\text { pain at } 4 \text { and } 9 \text { months. The } \\
\text { adjusted analysis evidenced } \\
\text { that younger women, those } \\
\text { with greater preoperative } \\
\text { psychological vulnerability } \\
\text { and decreased psychological } \\
\text { robustness, and those with } \\
\text { higher acute pain scores at rest } \\
\text { in the first postoperative week } \\
\text { were more likely to have } \\
\text { chronic pain at } 4 \text { months. }\end{array}$ & Bruce et al $^{8}$ \\
\hline $\begin{array}{l}\text { Retrospective } \\
\text { study }\end{array}$ & Thoracotomy & 320 patients & - & $\begin{array}{l}\text { Almost } 1 \text { in } 4 \text { patients under- } \\
\text { going thoracic surgery may } \\
\text { develop CPOP, } 1 / 3 \text { of them } \\
\text { accompanied by a neuropathic } \\
\text { component. Early prevention } \\
\text { and aggressive treatment are } \\
\text { important for high quality of } \\
\text { life of patients with CPOP after } \\
\text { thoracic surgery. }\end{array}$ & Peng et al $^{9}$ \\
\hline Editorial & - & - & - & $\begin{array}{l}\text { Re-evaluation of the criteria } \\
\text { that make up the definition of } \\
\text { CPOP. }\end{array}$ & $\begin{array}{l}\text { Werner and } \\
\text { Kongsgaard }^{6}\end{array}$ \\
\hline $\begin{array}{l}\text { Prospective } \\
\text { cohort }\end{array}$ & $\begin{array}{l}\text { Surgical excision } \\
\text { of breast tumor }\end{array}$ & 537 patients & $\begin{array}{l}\text { Preoperative, } 3 \text { days } \\
\text { after surgery, } \\
1 \text { week after surgery, } \\
6 \text { months after } \\
\text { surgery, } 1 \text { year } \\
\text { after surgery }\end{array}$ & $\begin{array}{l}\text { Both patient-related and treat- } \\
\text { ment-related risk factors predict } \\
\text { CPOP. Younger patients with } \\
\text { preoperative locoregional pain, } \\
\text { treated with axillary lymph node } \\
\text { dissection and high intensity of } \\
\text { acute postoperative pain (APOP) } \\
\text { and signs of neuropathic pain in } \\
\text { the acute phase of the postop- } \\
\text { erative period are at high risk. }\end{array}$ & $\begin{array}{l}\text { Andersen } \\
\text { et } \mathrm{al}^{10}\end{array}$ \\
\hline Review & - & - & - & $\begin{array}{l}\text { Government, colleges, and } \\
\text { patients gathered to discuss } \\
\text { chronic pain. Many risk factors } \\
\text { are known, but few measures } \\
\text { for prevention are taken. They } \\
\text { propose to carry out studies on } \\
\text { basic models of pain, among } \\
\text { them CPOP, to study it and its } \\
\text { prevention. Surgeries with } \\
\text { higher rates of CPOP: mastec- } \\
\text { tomy, thoracotomy, amputa- } \\
\text { tion, inguinal hernia repair. }\end{array}$ & $\begin{array}{l}\text { Gewandter } \\
\text { et } \mathrm{al}^{11}\end{array}$ \\
\hline $\begin{array}{l}\text { Prospective } \\
\text { longitudinal } \\
\text { cohort }\end{array}$ & Elective surgeries & 908 patients & $\begin{array}{l}1 \text { week before surgery, } \\
4 \text { days and } 1 \text { year after } \\
\text { surgery }\end{array}$ & $\begin{array}{l}\text { Prevalence - moderate to } \\
\text { severe preoperative pain: } 37.7 \% \text {; } \\
\text { acute postsurgical pain: } 26.7 \% \text {; } \\
\text { and CPOP: } 15.3 \% \text {. Risk factors } \\
\text { for the development of CPOP: } \\
\text { surgical specialty; preoperative }\end{array}$ & $\begin{array}{l}\text { Hoofwijk } \\
\text { et al }\end{array}$ \\
\hline
\end{tabular}


174 Chronic Postoperative Pain Oliveira et al.

Table 1 (Continued)

\begin{tabular}{|c|c|c|c|c|c|}
\hline Design & Procedure & Sample & Follow-up & Conclusion & Reference \\
\hline & & & & $\begin{array}{l}\text { pain; use of preoperative } \\
\text { analgesics; APOP; surgical fear; } \\
\text { lack of optimism;, and poor } \\
\text { preoperative quality of life. } \\
\text { Prevalence } \\
\text { of poor global recovery: } 22.3 \% \text {. }\end{array}$ & \\
\hline Review & - & - & - & $\begin{array}{l}\text { Five predictors contribute to } \\
\text { CPOP: preoperative pain in the } \\
\text { area to be operated on; CPOP } \\
\text { elsewhere in the body, such as } \\
\text { in the spine or hip; acute } \\
\text { postoperative pain; capacity } \\
\text { overload; and comorbid stress } \\
\text { symptoms such as anxiety, } \\
\text { rumination, magnification, } \\
\text { and helplessness. Chronic pain } \\
\text { may require a prolonged } \\
\text { course of analgesic medica- } \\
\text { tion, specifically opioids. }\end{array}$ & $\begin{array}{l}\text { Lavand' } \\
\text { homme and } \\
\text { Thienpont }^{13}\end{array}$ \\
\hline $\begin{array}{l}\text { Observational } \\
\text { study }\end{array}$ & $\begin{array}{l}\text { Total knee replacement } \\
\text { (TKR) }\end{array}$ & $\begin{array}{l}78 \text { patients with knee } \\
\text { osteoarthritis }(\mathrm{OA}) \text {, with no } \\
\text { other associated local } \\
\text { diseases }\end{array}$ & $\begin{array}{l}\text { Preoperative, } \\
2 \text { months, and } \\
12 \text { months after } \\
\text { surgery }\end{array}$ & $\begin{array}{l}\text { Preoperative pain intensity } \\
\text { and temporal summation (TS) } \\
\text { correlated with 12-month } \\
\text { postoperative pain intensity } \\
\text { and showed a trend toward } \\
\text { independence. The TS of pain } \\
\text { may be a mechanistic preop- } \\
\text { erative predictor of the devel- } \\
\text { opment of CPOP in patients } \\
\text { with knee OA after TKR } \\
\text { surgery. }\end{array}$ & $\begin{array}{l}\text { Petersen } \\
\text { et al }\end{array}$ \\
\hline Review & - & - & - & $\begin{array}{l}\text { Chronic pain is frequent; it } \\
\text { affects } \sim 20 \% \text { of people } \\
\text { worldwide, and accounts for } \\
15 \% \text { to } 20 \% \text { of physician visits. } \\
\text { Chronic pain should receive } \\
\text { greater attention as a global } \\
\text { health priority because } \\
\text { adequate pain treatment is a } \\
\text { human right, and it is the duty } \\
\text { of any health care system to } \\
\text { provide it. }\end{array}$ & $\begin{array}{l}\text { Treede } \\
\text { et }^{15}\end{array}$ \\
\hline Review & - & - & - & $\begin{array}{l}\text { The treatment of perioperative } \\
\text { pain has significantly developed } \\
\text { in the past } 20 \text { years. Detection of } \\
\text { new clinical entities such as } \\
\text { CPOP and the negative conse- } \\
\text { quences of the excessive use of } \\
\text { opioids have redefined the } \\
\text { treatment. The goal is a high- } \\
\text { quality perioperative analgesia } \\
\text { that minimizes the use of } \\
\text { opioids and thereby enables } \\
\text { rapid rehabilitation. }\end{array}$ & $\begin{array}{l}\text { Beloeil and } \\
\text { Sulpice }^{16}\end{array}$ \\
\hline $\begin{array}{l}\text { Prospective } \\
\text { cohort }\end{array}$ & Ventral hernia repair & 887 patients & $\begin{array}{l}\text { Preoperative } \\
1,6 \text {, and } 12 \text { months } \\
\text { after surgery }\end{array}$ & $\begin{array}{l}\text { Patients who have preopera- } \\
\text { tive pain are significantly more } \\
\text { likely to have chronic pain } \\
1 \text { month after surgery. }\end{array}$ & Cox et $\mathrm{al}^{17}$ \\
\hline $\begin{array}{l}\text { Prospective } \\
\text { cohort }\end{array}$ & Cesarian section & 527 women & $\begin{array}{l}3,6 \text {, and } 12 \text { months } \\
\text { after surgery }\end{array}$ & $\begin{array}{l}\text { In women undergoing Cesarian } \\
\text { section, CPOP was not uncom- } \\
\text { mon. Patients with more intense } \\
\text { postoperative pain in the } \\
\text { movement, preoperative } \\
\text { depression, and longer surgical } \\
\text { time presented a higher risk for } \\
\text { CPOP postoperatively. }\end{array}$ & Jin et $\mathrm{al}^{18}$ \\
\hline $\begin{array}{l}\text { Randomized } \\
\text { controlled } \\
\text { trial }\end{array}$ & $\begin{array}{l}\text { Traumatic tibial fracture } \\
\text { repair }\end{array}$ & 359 patients & $\begin{array}{l}6 \text { weeks after } \\
\text { surgery }\end{array}$ & $\begin{array}{l}\text { Out of } 267 \text { tibial fracture } \\
\text { patients with data available for } \\
\text { analysis, } 55.1 \% \text { reported CPOP } \\
1 \text { year after surgery. Applying } \\
\text { the Somatic Pre-Occupation } \\
\text { and Coping (SPOC) scores, the }\end{array}$ & Khan et al $^{19}$ \\
\hline
\end{tabular}


Chronic Postoperative Pain Oliveira et al. 175

Table 1 (Continued)

\begin{tabular}{|c|c|c|c|c|c|}
\hline Design & Procedure & Sample & Follow-up & Conclusion & Reference \\
\hline & & & & $\begin{array}{l}\text { CPOP was of } 37.6 \%, 54.1 \% \text {, and } \\
81.7 \% \text { among patients with } \\
\text { low }(\leq 40) \text {, intermediate } \\
(41-80) \text {, and high }(>80) \\
\text { scores respectively. The } \\
\text { patients' coping and expecta- } \\
\text { tions of recovery, measured by } \\
\text { the SPOC questionnaire, are an } \\
\text { independent } \\
\text { predictors of CPOP and pain } \\
\text { interference one year after } \\
\text { traumatic tibial fracture. }\end{array}$ & \\
\hline $\begin{array}{l}\text { Prospective } \\
\text { cohort }\end{array}$ & $\begin{array}{l}\text { Elective surgical interven- } \\
\text { tions including joint (hip } \\
\text { arthroplasty, knee), back } \\
\text { (nucleotomy, spondylosis) } \\
\text { or urologic (cystectomy, } \\
\text { prostatectomy, nephrec- } \\
\text { tomy) surgeries. }\end{array}$ & 644 patients & $\begin{array}{l}2 \text { days and } 6 \text { months } \\
\text { after surgery }\end{array}$ & $\begin{array}{l}\text { A significant number of } \\
\text { patients suffer from pain and } \\
\text { need analgesic medication, } \\
\text { even opiates, up to } 6 \text { months } \\
\text { after surgery. }\end{array}$ & $\begin{array}{l}\text { Laufenberg- } \\
\text { Feldmann } \\
\text { et } \mathrm{al}^{20}\end{array}$ \\
\hline Review & - & - & - & $\begin{array}{l}\text { Based on the pathophysiolog- } \\
\text { ical discussion and the risk } \\
\text { factors that contribute to the } \\
\text { chronification of postopera- } \\
\text { tive pain, topics are suggested } \\
\text { that still need studies to be } \\
\text { performed to contribute to } \\
\text { better pain management. }\end{array}$ & $\begin{array}{l}\text { Pozek } \\
\text { et }^{21}{ }^{21}\end{array}$ \\
\hline $\begin{array}{l}\text { Observational } \\
\text { study }\end{array}$ & $\begin{array}{l}\text { Knee arthroplasty (partial } \\
\text { or total) }\end{array}$ & 104 patients & 3 and 6 months & $\begin{array}{l}\text { Several pre- and postoperative } \\
\text { features could be used to } \\
\text { facilitate the identification of } \\
\text { patients at high risk for CPOP } \\
\text { after knee surgery. All thera- } \\
\text { peutic strategies that decrease } \\
\text { APOP, such as controlling } \\
\text { anxiety or performing a knee } \\
\text { replacement before pain, have } \\
\text { serious effects on walking } \\
\text { ability, and may help reduce } \\
\text { the risk of CPOP. }\end{array}$ & $\begin{array}{l}\text { Thomazeau } \\
\text { et } \mathrm{al}^{22}\end{array}$ \\
\hline Review & - & $\begin{array}{l}66 \text { World Health Organiza- } \\
\text { tion member states with } \\
\text { data available }\end{array}$ & 2005 to 2012 & $\begin{array}{l}266.2 \text { to } 359.5 \text { million opera- } \\
\text { tions were performed in } 2012 \text {. } \\
\text { This represents an increase of } \\
38 \% \text { over the previous } 8 \text { years. } \\
\text { The largest increase in opera- } \\
\text { tions was in very-low- and } \\
\text { low-expenditure Member } \\
\text { States. Surgical data were } \\
\text { lacking for many Member } \\
\text { States. }\end{array}$ & Weiser et al $^{1}$ \\
\hline $\begin{array}{l}\text { Prospective } \\
\text { observational }\end{array}$ & $\begin{array}{l}\text { Thoracotomy, video thora- } \\
\text { coscopy, thoracoscopy }\end{array}$ & 206 patients & $\begin{array}{l}3 \text { days and } 6 \text { months } \\
\text { after surgery }\end{array}$ & $\begin{array}{l}\text { No difference was found in the } \\
\text { incidence and severity of } \\
\text { chronic pain } 6 \text { months after } \\
\text { surgery in patients undergo- } \\
\text { ing thoracotomy versus thor- } \\
\text { acoscopy. Unlike other } \\
\text { postsurgical pain conditions, } \\
\text { none of the preoperative psy- } \\
\text { chosocial measurements were } \\
\text { associated with chronic pain } \\
\text { after thoracic surgery. }\end{array}$ & $\begin{array}{l}\text { Bayman } \\
\text { et } \mathrm{a}^{23}\end{array}$ \\
\hline $\begin{array}{l}\text { Observational } \\
\text { cohort }\end{array}$ & Inguinal hernia repair & 108 patients & $\begin{array}{l}15 \text { days and } \\
2 \text { months after } \\
\text { surgery }\end{array}$ & $\begin{array}{l}\text { Chronic postsurgical pain is } \\
\text { frequent in this type of } \\
\text { surgery. The use of periopera- } \\
\text { tive analgesia along with } \\
\text { prevention and management } \\
\text { of pain in the first postopera- } \\
\text { tive weeks help to prevent the } \\
\text { development of chronic post- } \\
\text { surgical pain. General anes- } \\
\text { thesia may increase the risk of } \\
\text { it. Similar studies conducted } \\
\text { on a larger scale could help }\end{array}$ & $\begin{array}{l}\text { Hermida } \\
\text { et } \mathrm{al}^{24}\end{array}$ \\
\hline
\end{tabular}


Table 1 (Continued)

\begin{tabular}{|c|c|c|c|c|c|}
\hline Design & Procedure & Sample & Follow-up & Conclusion & Reference \\
\hline & & & & $\begin{array}{l}\text { identify other associated } \\
\text { factors. }\end{array}$ & \\
\hline Review & - & - & - & $\begin{array}{l}\text { Chronic postsurgical pain may } \\
\text { occur regardless of the type of } \\
\text { procedure, although some } \\
\text { surgeries carry a higher risk in } \\
\text { relation to the degree of tissue } \\
\text { damage and the potential for a } \\
\text { major inflammatory reaction } \\
\text { or nerve injury. CPOP resolves } \\
\text { over time. Of all patients with } \\
\text { CPOP } 6 \text { months after surgery, } \\
55.8 \% \text { will be pain-free at } \\
12 \text { months, whereas } 2.9 \% \text { of } \\
\text { patients without pain at } \\
6 \text { months will report some } \\
\text { pain at } 12 \text { months. Mental } \\
\text { health has an important } \\
\text { impact on the patient's ability } \\
\text { to recover after surgery. }\end{array}$ & $\begin{array}{l}\text { Lavand' } \\
\text { homme }^{25}\end{array}$ \\
\hline Editorial & - & - & - & $\begin{array}{l}\text { Early identification of patients } \\
\text { at risk will help reduce the } \\
\text { percentage of patients who } \\
\text { develop CPOP. }\end{array}$ & $\begin{array}{l}\text { Tawfic } \\
\text { et } \mathrm{al}^{26}\end{array}$ \\
\hline Review & - & - & - & $\begin{array}{l}\text { Chronic pain in general has an } \\
\text { association with difficulty in } \\
\text { coping, socioeconomic } \\
\text { aspects (poverty, access to } \\
\text { health/medication), and } \\
\text { comorbidities (anxiety, } \\
\text { depression, alcoholism, opioid } \\
\text { dependence). }\end{array}$ & $\begin{array}{l}\text { Borsook } \\
\text { et } \mathrm{al}^{27}\end{array}$ \\
\hline $\begin{array}{l}\text { Prospective } \\
\text { cohort }\end{array}$ & $\begin{array}{l}\text { Hysterectomy (any } \\
\text { technique) }\end{array}$ & 170 women & $\begin{array}{l}24 \text { hours, } 48 \text { hours, } \\
4 \text { months and } \\
5 \text { years after surgery }\end{array}$ & $\begin{array}{l}\text { Pain trajectory: } 51.8 \% \text { of the } \\
\text { women without pain at } \\
4 \text { months; } 31.2 \% \text { with pain at } \\
4 \text { months, but not at } 5 \text { years; } \\
17.1 \% \text { with pain at } 4 \text { months } \\
\text { and at } 5 \text { years. Major risk } \\
\text { factors: preoperative anxiety, } \\
\text { emotional repercussions of } \\
\text { the disease, catastrophization. } \\
\text { Greater postoperative anxiety } \\
\text { and frequency/intensity of } \\
\text { acute pain after surgery have a } \\
\text { worse trajectory of pain. Acute } \\
\text { variables had a greater impact } \\
5 \text { years after surgery, and } \\
\text { should be treated properly } \\
\text { with APOP. }\end{array}$ & $\begin{array}{l}\text { Pinto } \\
\text { et } \mathrm{al}^{28}\end{array}$ \\
\hline Review & - & - & - & $\begin{array}{l}\text { An optimal postoperative pain } \\
\text { management requires } \\
\text { evidence-based guidance from } \\
\text { published guidelines and } \\
\text { clinical experts, and must } \\
\text { consider individual patient } \\
\text { values and preferences. }\end{array}$ & $\begin{array}{l}\text { Manworren } \\
\text { et } \mathrm{al}^{29}\end{array}$ \\
\hline
\end{tabular}

have been increasingly studied and identified in scientific research within large surgical fields. Therefore, the professionals dedicated to each surgical specialty seek to obtain parameters that can improve patient care.

The risk factors for CPOP can be grouped into five major domains: clinical, demographic, psychological, surgery-related, and pain-related. ${ }^{28}$ Thus, based on the knowledge of the variables that may predispose patients to the onset of CPOP, it is important to identify the susceptible individuals to take measures that positively interfere in the postoperative result in the short and long terms, ${ }^{18}$ since a range of factors can intertwine and impact on patient evolution.
The age of the patient has been correlated with the process of postoperative pain chronification in several studies. Younger patients are more likely to present with $\mathrm{CPOP}^{8,17,19,21,26}$ especially those under the age of 60 years. $^{9}$

The influence of gender as a risk factor has also been observed, ${ }^{4}$ since females are more affected by CPOP. $9,17,19,21,26$ In relation to ethnicity, non-Caucasian patients have been more associated with CPOP than other patients after hernia repair. ${ }^{17}$ Genetic peculiarities have also been shown to participate in the genesis of CPOP, a field of study that has been slowly growing. ${ }^{10,16,21,26}$ 
Socioeconomic characteristics, ${ }^{4}$ such as having higher education ${ }^{22}$ and a job, ${ }^{24}$ have been recognized as risk factors. The lifestyle habits of the patients also matter, inasmuch as sedentary adults who underwent orthopedic surgery have had more CPOP. ${ }^{22}$

The presence of psychological changes prior to the surgical procedure is a risk factor for CPOP. ${ }^{4,8,13,16,18,19,25}$ Associations between depression, ${ }^{8,10,21,26,28}$ anxiety, ${ }^{10,13,21,22,26,28}$ and difficulty coping with pain have been identified as risk factors for CPOP. ${ }^{19,22,27}$ Even the patient's expectations regarding the surgery to be performed may become a risk factor for chronic pain. $^{4}$

Psychological factors are so important for CPOP that led to the inquiry on the role of pain catastrophizing by the patient, a process by which the individual has a negative response exacerbated by an adverse stimulus. ${ }^{8}$ The use of the Pain Catastrophizing Scale in patients that underwent breast cancer surgery revealed a greater presence of CPOP four months after the procedure in those who had suffered from catastrophic pain. This finding has been corroborated in different surgical specialties. ${ }^{19,21,28}$

The incidence of pain prior to surgery, in any part of the body, is also a well-known risk factor for CPOP. ${ }^{13,15,16,22,25,27,28}$ It is also known that algic syndromes such as fibromyalgia and migraine play a role in the predisposition for CPOP, although their magnitude is yet to be revealed. ${ }^{13,21,30}$

The surgical procedure itself involves a large dimension of risk factors. Several studies have indicated the type of surgery as a major predisposing factor for CPOP. $^{4,10,16-18,21,26,28,31}$ Variations in CPOP incidence may depend on the duration of the surgery, ${ }^{18,21}$ the experience of the surgeon, and the anesthetic technique used during the surgical procedure. ${ }^{12,21,24}$

Postoperative events should also be monitored, since the role of acute pain in this period has long been well-established. High risk factors for CPOP are the high intensity of acute pain, ${ }^{18,20,21,24-26,28,29}$ the lack of analgesia approach, or its inefficiency. $4,9,21,24,32,33$

In each surgical specialty, the management of CPOP should be optimized, since each procedure has its own peculiarities. The maintenance of postoperative chest tube drainage for at least 4 days after thoracic surgeries ${ }^{9}$ and the administration of more than $6 \mathrm{mg}$ of morphine in the first 48 hours after urological surgeries ${ }^{7}$ have been identified as predictive factors for CPOP. Postoperative complications also predispose to pain chronification, as demonstrated in breast and orthopedic surgical procedures. ${ }^{8,22}$

\section{CPOP in Orthopedic Surgeries}

Due to the increase in human longevity and the development of health resources, more orthopedic procedures are needed and performed around the world every year. About 500,000 total knee arthroplasties are performed in the United States a year, and up to $20 \%$ of these patients develop CPOP. In a study with 78 patients submitted to this procedure, 22\% had moderate to severe CPOP. ${ }^{14}$

Another study performed with 104 patients submitted to knee arthroplasty found that $10 \%$ to $34 \%$ of them had CPOP, and $28.8 \%$ remained with pain 6 months after surgery. Additionally, the intensity of pain in the first four postoperative days was strongly associated with pain chronification. ${ }^{22}$

Among patients who underwent knee arthroplasty, 15\% to $20 \%$ were dissatisfied with the result due to the occurrence of pain, ${ }^{13}$ with a great negative impact on their lives. A total of $55.1 \%$ of the patients who underwent surgery for traumatic tibial fracture reported moderate to severe pain 1 year after the procedure, culminating in negative impact on the daily activities in $35.2 \%$ of the cases. ${ }^{19}$

\section{CPOP in Gynecologic, Obstetric, and Breast Surgeries}

The most common gynecological surgery performed in the West is hysterectomy. A review of 11 2-year follow-up studies showed that $5 \%$ to $32 \%$ of hysterectomized patients had CPOP. ${ }^{28}$ The study encompassed a sample of 170 women who were evaluated from 24 hours to 5 years after surgery, and almost half of them reported pain after 4 months; of these, $17.1 \%$ still felt pain 5 years after the hysterectomy.

In obstetrics, the focus is Cesarean section, a procedure that has been increasingly performed worldwide, despite the ideal rate of $10 \%$ to $15 \%$ of the total deliveries accepted by the international healthcare community since $1985 .{ }^{34}$ In China, for example, up to $80 \%$ of births are Cesarean sections. ${ }^{18}$ However, despite the number of these procedures, there are few data available that address the presence of CPOP in these women.

A total of 527 patients submitted to Cesarian section included in an observational cohort study ${ }^{18}$ were followed up from the preoperative period up to 12 months postoperatively. Pain was reported by $18.3 \%, 11.3 \%$, and $6.8 \%$ of the patients 3,6 , and 12 months after the procedure respectively. The impact on the lives of these patients was evident, because 3 months after the Cesarian section $84.4 \%$ of the patients with pain revealed that they had impairments in their daily activities. At 6 and 12 months, they complained of mood disorders and reduced joy of living caused by chronic pain. Long-term analgesic use after Cesarian section has also been reported by $21.9 \%$ of the patients with CPOP 12 months after the procedure. ${ }^{18}$

Approximately half of the women who underwent breast cancer surgery reported CPOP after 3 years. The pain complaints may persist for up to 12 years, which decreases their quality of life. Up to $23 \%$ of the patients submitted to breast cancer surgery have reported unbearable pain 4 months after the procedure. $^{8}$ of 537 women that participated in a prospective cohort study, ${ }^{10}$ between $25 \%$ and $60 \%$ complained of reduced physical functioning, and $7 \%$ reported pain when moving even 1 year after surgery.

\section{CPOP in General Surgeries}

An estimated 360,000 ventral and incisional hernioplasties are performed each year in the United States. Chronic postoperative pain has been referred by up to $39 \%$ of the patients submitted to ventral repairs, ${ }^{17}$ and by around $50 \%$ of the cases of inguinal hernia surgeries, of which $11.5 \%$ may have pain that persists for up to 1 year after hernioplasty. ${ }^{24}$

A total of 887 patients who underwent ventral hernioplasty (through the open or laparoscopic techniques) were followed up for 1 month, 6 months, and 1 year to assess quality of life 
and functionality after the procedure. ${ }^{17}$ Among the patients who did not have preoperative pain, $14.6 \%$ had pain at 6 months, and $12.6 \%$, at 1 year. Those who already had pain before surgery exhibited more alarming outcomes: $37.2 \%$ reported pain at 6 months, while $34.7 \%$ complained of pain at 1 year. These findings corroborate the importance of the presence of preoperative pain in the development of CPOP.

In relation to inguinal hernioplasties, the prevalence of CPOP has been associated with the surgical method applied: after open approaches, up to $7.3 \%$ of the patients complain about it, while after videolaparoscopic approaches this rate is reduced to $5 \%{ }^{24}$

\section{CPOP in Thoracic Surgeries}

Thoracic surgeries greatly contribute to the development of CPOP, including thoracoscopy. The emergence of chronic pain is present among $14 \%$ to $83 \%$ of the patients submitted to thoracic surgical procedures. ${ }^{9}$ Regardless of the technique, $27 \%$ of the patients evaluated 6 months after thoracic surgeries had CPOP, and $8.2 \%$ of them had limitations in daily activities. ${ }^{23}$
In a large scale study ${ }^{9}$ that included a sample of 1,284 patients who underwent thoracotomies and video-assisted thoracotomies, the authors concluded that $24.9 \%$ of them had CPOP. The patients' quality of life declined, especially among those who reported severe pain (4.3\%), reinforcing the damage caused to their lives.

\section{Proper Management of CPOP}

No consensual definition of what constitutes proper perioperative pain management has been reached so far. This gap reflects a lack of well-established criteria and of agreement on the parameters that may support the multidisciplinary team in the conduction of the patient. ${ }^{35}$ Thus, no ideal analgesia and no gold standard therapy have been recommended yet, because each case should be planned and analyzed individually. ${ }^{36}$ Based on the literature review and on the fact that CPOP is the main surgical complication of APOP that is not adequately treated, its proper management should target preventing pain chronification with actions performed before, during, and after surgery (-Fig. 2).

\section{PROPER PATIENT CARE AT THE HEALTH SYSTEM}
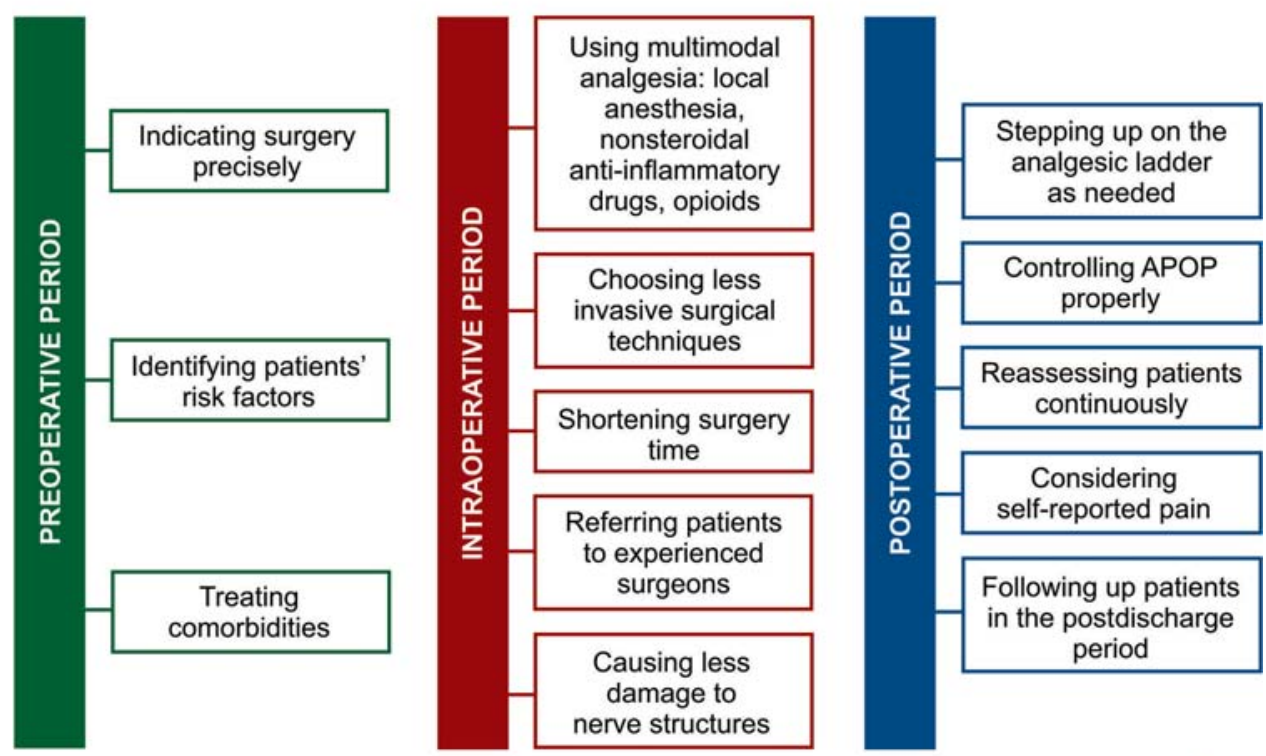

\section{REQUIREMENTS FOR PROPER PAIN MANAGEMENT}

\begin{tabular}{|cc|}
\hline a & $\begin{array}{c}\text { Trained multidisciplinary team } \\
\text { support }\end{array}$ \\
\hline a & Continuous reevaluation \\
\hline a & Psychological support \\
\hline Individualization of the treatment \\
\hline
\end{tabular}

Fig. 2 Proper approach of patients undergoing surgery. 


\section{Preoperative Period}

To properly manage CPOP, in the preoperative period it is necessary: 1) to identify the risk factors for chronic pain in advance, observing patients who may require special attention for the control of APOP; 2) to integrate pain control into other aspects of preparation and recovery of surgery, such as patient education, mobility, or nutrition and fluid intake; 3 ) to take into account the differences between patients in terms of experience and how they report pain; 4) and to organize the control of pre-, intra-, and postoperative pain according to an appropriate context and availability of the health system to improve treatment quality and safety. ${ }^{35,37,38}$

Preemptive analgesia is initiated before the surgical procedure to prevent pain in the early postoperative period, even before the surgical incision or any other painful procedures. It is effective, because it reduces the need for painkillers in the postoperative period. ${ }^{39}$

\section{Intraoperative Period}

A multimodal approach adopted to manage CPOP in the intraoperative period combines various types of medications such as anti-inflammatory drugs and local anesthesia to reduce dependence on a single agent. In addition, the individualized choice of anesthetic technique associated with peripheral or neuroaxis blocks optimizes the therapeutic plan for a better control of postoperative pain. ${ }^{36-38}$ It represents the possibility of action at various levels of pain pathways, enabling the insertion of other drugs and procedures, simultaneously improving the quality of the postoperative period. ${ }^{39}$

Another important step for the prevention of CPOP is to raise surgeon awareness of the use of measures to avoid intraoperative neural injury and the control of symptoms by treating them and changing the neuroplasticity induced in the central nervous system (CNS) with such an injury. Thus, multimodal treatments should be used to act in the progression of the mechanisms triggered by pain. ${ }^{33}$

\section{Postoperative Period}

An investigative approach has been designed to reduce acute pain during or shortly after a painful stimulus to decrease the potential development of chronic pain: the Initiative on Methods, Measurement, and Pain Assessment in Clinical Trials (IMMPACT). The recommendations of IMMPACT include the evaluation of pain intensity and physical and emotional response as a central result in chronic pain tests. It is recommended to emphasize pain outcomes, such as presence and severity, to illustrate several methodological issues in the prevention setting. ${ }^{11}$

Almost all types of pain after surgery can and should be managed to optimize the patients' emotional function. The intensity of pain at rest and with movement should be assessed, which is relevant to adapt pain therapy to rehabilitation needs. Additionally, the continuous assessment of the patient after discharge is highly important to recognize and treat persistent pain and any other unwanted surgical consequences as soon as possible. ${ }^{37,38}$

The evaluations of pain aim to recognize the initial functional recovery through the patient's report on the intensity of pain, interference in activities of daily living, presence and severity of adverse effects, and the patient's perception of the treatment received. The targets should, whenever possible, include pain no worse than mild and minimal interference with function and treatment. A graphical representation of pain intensity scores during the observational period, compared with a single pain score, draws attention to the speed at which pain relief begins, the consistency of this improvement, and the total amount of relief achieved. ${ }^{35}$

\section{Healthcare Team Training Program}

An important measure to achieve adequate management of APOP is to enable healthcare professionals to understand pain as an avoidable and unnatural phenomenon, recognizing it as the fifth vital sign, which is influenced by the psychological and social aspects of the individual. ${ }^{39,40}$ Since the academic background in pain has been greatly neglected in most healthcare curricula, postoperative analgesia remains inadequate. ${ }^{33}$ Consequently, the dedication of healthcare professionals to the adequate management of postoperative pain is a humanitarian act, fundamental to achieve quality in patient care in a global scenario of inadequate management of pain.

It is recognized that the treatment of pain should become a medical subspecialty due to the growth in knowledge and specialized techniques such as regional anesthesia. ${ }^{37}$ This targeted approach can reduce or avoid the adverse effects of undertreated APOP, such as increased risk of maintenance or transition to $\mathrm{CPOP}^{38}$

\section{Conclusion}

Chronic postoperative pain is a clinical disease with a major impact on morbidity rates in Brazil and in the world, which implies high costs for the health system. With multifactorial causality, it is still much neglected by healthcare professionals, and it is sometimes ignored in their training programs, directly reflecting on the quality of life of the patients after surgical procedures. Therefore, the management of APOP becomes deficient, making it the main risk factor for the development of CPOP.

It is necessary to improve the training of healthcare professionals in the management of pain symptoms before, during, and after surgeries. In addition to this, more in-depth studies should be performed for the evaluation and management of this condition. It is worth mentioning that the multimodal approach should take place pre-, intra-, and postoperatively based on the individualization of the treatment.

\section{Conflict of Interests}

The authors have no conflict of interests to declare.

\section{References}

1 Weiser TG, Haynes AB, Molina G, et al. Size and distribution of the global volume of surgery in 2012. Bull World Health Organ 2016; 94(03):201-209F. Doi: 10.2471/BLT.15.159293 
2 Merskey H, Albe Fessard D, Bonica JJ, et al; Recommended by the IASP Subcommittee on Taxonomy. Pain terms: a list with definitions and notes on usage. Pain 1979;6(03):249-252

3 Martins CAS, Aragão FF. Post-operative pain: concepts and pathophysiology. Rev Dor 2017;18(Suppl 1):2-7

4 Souza LCB, Alves LB. Consequences of postoperative pain and clinical implications of untreated postoperative pain. Rev Dor 2017;18(Suppl 1):14-19

5 Kraychete DC, Castro APCR, Miranda LL. Peripheral sensitization, central sensitization and postoperative pain chronification. Rev Dor 2017;18(Suppl 1):20-23

6 Werner MU, Kongsgaard UE. I. Defining persistent post-surgical pain: is an update required? Br J Anaesth 2014;113(01):1-4. Doi: 10.1093/bja/aeu012

7 Artus M, Laviolle B, Maurice A, Malledant Y, Beloeil H. Risk factors for persistent pain after urological surgery. Ann Fr Anesth Reanim 2014;33(05):e89-e94. Doi: 10.1016/j.annfar.2014.03.013

8 Bruce J, Thornton AJ, Powell R, et al; Recovery Study Group. Psychological, surgical, and sociodemographic predictors of pain outcomes after breast cancer surgery: a population-based cohort study. Pain 2014;155(02):232-243. Doi: 10.1016/j.pain.2013.09.028

9 Peng Z, Li H, Zhang C, Qian X, Feng Z, Zhu S. A retrospective study of chronic post-surgical pain following thoracic surgery: prevalence, risk factors, incidence of neuropathic component, and impact on qualify of life. PLoS One 2014;9(02):e90014. Doi: 10.1371/journal.pone.0090014

10 Andersen KG, Duriaud HM, Jensen HE, Kroman N, Kehlet H. Predictive factors for the development of persistent pain after breast cancer surgery. Pain 2015;156(12):2413-2422. Doi: 10.1097/j.pain.0000000000000298

11 Gewandter JS, Dworkin RH, Turk DC, et al. Research design considerations for chronic pain prevention clinical trials: IMMPACT recommendations. Pain 2015;156(07):1184-1197. Doi: $10.1097 /$ j.pain.0000000000000191

12 Hoofwijk DMN, Fiddelers AAA, Peters ML, et al. Prevalence and predictive factors of chronic postsurgical pain and poor global recovery 1 year after outpatient surgery. Clin J Pain 2015;31(12): 1017-1025. Doi: 10.1097/AJP.0000000000000207

13 Lavand'homme P, Thienpont E. Pain after total knee arthroplasty: a narrative review focusing on the stratification of patients at risk for persistent pain. Bone Joint J 2015;97-B(10, Suppl A)45-48. Doi: 10.1302/0301-620X.97B10.36524

14 Petersen KK, Arendt-Nielsen L, Simonsen O, Wilder-Smith O, Laursen MB. Presurgical assessment of temporal summation of pain predicts the development of chronic postoperative pain 12 months after total knee replacement. Pain 2015;156(01): 55-61. Doi: $10.1016 /$ j.pain.0000000000000022

15 Treede RD, Rief W, Barke A, et al. A classification of chronic pain for ICD-11. Pain 2015;156(06):1003-1007. Doi: 10.1097/j.pain.000000 0000000160

16 Beloeil H, Sulpice L. Peri-operative pain and its consequences. JVisc Surg 2016;153(6S, suppl.)S15-S18. Doi: 10.1016/j.jviscsurg. 2016.09.004

17 Cox TC, Huntington CR, Blair LJ, et al. Predictive modeling for chronic pain after ventral hernia repair. Am J Surg 2016;212(03): 501-510. Doi: 10.1016/j.amjsurg.2016.02.021

18 Jin J, Peng L, Chen Q et al. Prevalence and risk factors for chronic pain following cesarean section: a prospective study. BMC Anesthesiol 2016;16(01):99. Doi: 10.1186/s12871-016-0270-6

19 Khan JS, Devereaux PJ, LeManach Y, Busse JW. Patient coping and expectations about recovery predict the development of chronic post-surgical pain after traumatic tibial fracture repair. $\mathrm{Br} \mathrm{J}$ Anaesth 2016;117(03):365-370. Doi: 10.1093/bja/aew225
20 Laufenberg-Feldmann R, Kappis B, Mauff S, Schmidtmann I, Ferner M. Prevalence of pain 6 months after surgery: a prospective observational study. BMC Anesthesiol 2016;16(01):91. Doi: 10.1186/s12871-016-0261-7

21 Pozek JPJ, Beausang D, Baratta JL, Viscusi ER. The acute to chronic pain transition: can chronic pain be prevented? Med Clin North Am 2016;100(01):17-30. Doi: 10.1016/j.mcna.2015.08.005

22 Thomazeau J, Rouquette A, Martinez V, et al. Predictive factors of chronic post-surgical pain at 6 months following knee replacement: influence of postoperative pain trajectory and genetics. Pain Physician 2016;19(05):E729-E741

23 Bayman EO, Parekh KR, Keech J, Selte A, Brennan TJ. A prospective study of chronic pain after thoracic surgery. Anesthesiology 2017; 126(05):938-951. Doi: 10.1097/ALN.0000000000001576

24 Hermida PAC, Zamarra DRB, Nope CG, Mendoza EFB. Incidence of chronic post-surgical pain and its associated factors in patients taken to inguinal hernia repair. Colomb J Anesthesiol 2017;45 (04):291-299. Doi: 10.1016/j.rcae.2017.07.002

25 Lavand'homme P. Transition from acute to chronic pain after surgery. Pain 2017;158(Suppl 1):S50-S54. Doi: 10.1097/j. pain.0000000000000809

26 Tawfic Q, Kumar K, Pirani Z, Armstrong K. Prevention of chronic post-surgical pain: the importance of early identification of risk factors. J Anesth 2017;31(03):424-431. Doi: 10.1007/s00540017-2339-x

27 Borsook D, Youssef AM, Simons L, Elman I, Eccleston C. When pain gets stuck: the evolution of pain chronification and treatment resistance. Pain 2018;159(12):2421-2436. Doi: 10.1097/j. pain.0000000000001401

28 Pinto PR, McIntyre T, Araújo-Soares V, Almeida A, Costa P. Psychological factors predict an unfavorable pain trajectory after hysterectomy: a prospective cohort study on chronic postsurgical pain. Pain 2018;159(05):956-967. Doi: 10.1097/j.pain.00000000 00001170

29 Manworren RCB, Gordon DB, Montgomery R. CE: Managing Postoperative Pain. Am J Nurs 2018;118(01):36-43. Doi: 10.1097/01.NAJ.0000529695.38192.67

30 Jones I, Bari F. Chronic pain after surgery. Surgery 2017;35(02): 106-109. Doi: 10.1016/j.mpsur.2016.11.005

31 Lavand'homme P, Pogatzki-Zhan E. Chronic postsurgical pain: definition, impact, and prevention. Washington, DC: IASP; 2017. (Fact Sheet No 4).

32 Guimarães GMN, Silva HBC, Machado RCS. Predictive factors for postoperative pain chronification. Rev Dor 2017;18 (Suppl 1):24-28

33 Montarroyos ES, Pimentel ICP, Yin CY. Why postoperative pain is not adequately treated. Rev Dor 2017;18(Suppl 1):8-13

34 WHO. WHO Statement on Caesarean section rates. Geneva: World Health Organization; 2015

35 Gordon D, Meissner W, Zaslansky R. Using outcomes to improve pain care after surgery. Washington, DC: IASP; 2017. (Fact Sheet No 14).

36 Canga JC, Abreu YLB, Fogaça RJ. Multimodal analgesia in postoperative pain. Rev Dor 2017;18(Suppl 1):47-51

37 Carr DB, Morlion B. What the public should know about pain after surgery. Washington, DC: IASP; 2017. (Fact Sheet No 1).

38 Carr DB, Morlion B. Pain after surgery: what health-care professionals should know. Washington, DC: IASP; 2017. (Fact Sheet No 2).

39 Barros CM, Ferreira MO, Carvalho BFV. Basis of postoperative pain treatment. Rev Dor 2017;18(Suppl 1):41-46

40 Pinto CMI, Santos J. Postoperative pain as the fifth vital sign. Rev Dor 2017;18(Suppl 1):33-36 